\title{
Local varieties vines in the Republic of Bulgaria (pink varieties)
}

\author{
Plamena Yankoval ${ }^{1}$ Anatoli Iliev ${ }^{2}$ \\ 1 - Technical University of Varna, Department of Plant Production, 9010, 1 Studentska Street, Varna, Bulgaria \\ 2 - Institute of Viticulture and Enology, 5800, 1 Kala tepe Street, Pleven, Bulgaria
}

Corresponding author contact: pl yankovalabv.bg

\begin{abstract}
The present paper focuses primarily on the agrobiological and technological characteristics of the pink local vinous varieties Pamid and Muscat red. Muscat red is a late ripening vinous variety, and variety Pamid is a medium ripening vinous variety with possibility for consumption in fresh condition as well since its pellicle and seeds are not felt, and the titrated acidity is low. Variety Muscat red belongs to the most cold-resistant local varieties. Variety Pamid has increased root phylloxera resistance, on account of which it can be cultivated on its own roots without grafting in sandy soils.
\end{abstract}

Keywords: local, Muscat red, Pamid, sort, variety

\section{Introduction}

Vine is one of the most important agricultural crops for our country. Prerequisites for this are the excellent climatic and soil conditions and also the considerable professional experience of its cultivation. Until the 60's of the previous century the wine-growing production is determined by the local varieties Pamid, Mavroud and Wide Melnik vine, cultivated in south and south-western Bulgaria, Gamza in north-western Bulgaria, Dimyat in east Bulgaria and along the Black Sea coast and Muscat red in the Sub-Balkan valley from town of Karlovo to town of Sungurlare and at separate locations in the Sredna Gora region (Радулов и др., 2004). Their wines appear to be gaining in international popularity and recognition, with certain interest and preference being manifested towards them (Катеров и др., 1990).

After the establishment of vine-growing zonation in the country and the transition towards the industrial technologies for production of grapes, the percentage of the areas, planted with local varieties after the 70's -80 's of the previous century is highly restricted. As a result of the socio-economic changes that occurred in the country in the 90's of the previous century, the areas of the vineyards, inclusive of those, occupied with local varieties, are substantially reduced.

Oversaturation on the wine market of the traditional widely spread vinous varieties Cabernet Sauvignon, Merlot, Syrah, Chardonnay, Muscat Ottonel and etc. is observed on world scale. The consumers' interest becomes more and more increased towards the wines, which are obtained by local and newlyselected varieties. It is necessary to be given priority with the planting and cultivation of local vinous varieties of vines in order to be retrieved the authority of the Bulgarian authentical wine on the home and international market.

The purpose of the present paper is to offer a brief overview of the principal agrobiological and technological characteristics of the most important local vinous varieties for Bulgaria.

\section{$2 \quad$ Material and methods}

The researches into the varieties are carried out under immaculate collectible and production conditions of the narrow-line ground plantations with Guyot formation and eye loading corresponding to the variety. provided, additionally, as for the basic varieties, is further information about their cultivation with wide-line production plantations with a free crown, a formation type „Umbrella” or „Moser”. 


\section{Results and discussion}

\section{MUSCAT RED}

SYNONYMS. Karlovo muscat, Kimionka, Muscat grey, Stara Zagora Muscat, Blue violet, The blue violet, Sungurlare muscat, Violet blue, Turkish ruzhitsa, south Bulgarian red muscat.

ORIGIN. Muscat red (fig.1) is a variety of local origin (Катеров и Костов, 196). It is not found in other countries and foreign names and synonyms are not known, which would cause doubts about its local origin. It belongs to the eco-geographical group of Black Sea (Proles pontica Negr.).

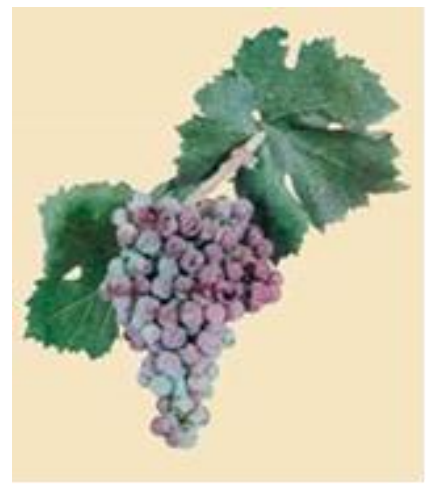

Fig. 1. Muscat red

DISTRIBUTION. Bulgaria has cultivated red Muscat variety since ancient times mainly in the micro regions around Karlovo, Sungurlare, village of Prosenik and village of Straldzha. It occupies restricted areas around Sliven, Stara Zagora and Varna. In 1976 it occupies around $6 \%$ of the total area of the vineyards and around $11 \%$ of the area of the white vinous varieties. It is zoned for industrial cultivation in the east and south vine-growing region of the country (Стоев и др, 1960). As of 2010 in Bulgaria the relative share of the vine plantations growing red Muscat variety is $20 \%$ of the total share of the areas with white vinous varieties (М3X, „Агростатистика“, 2011).

PERIOD OF VEGETATION. Muscat red is a late ripening vinous variety - the grapes ripes during the second half of September, even in the beginning of October.

GROWING STRENGTH OF THE VINES. The vines are of medium growth. The shoots are rightgrowing. They form slightly developed side shoots. The leaves are arranged one above each other, with the upper ones overlapping the lower ones (this is typical). The vines are known to produce ample amounts of leaves.

FERTILITY AND CROP. With ground cultivation and Guyot formation the red Muscat variety has high values of the indexes for fertility and crop. The shoots with two racemes prevail. The values of the bud- fertility indexes are moderately high. The racemes are located on the 4-th and 5-th knot of the shoot. The average weight of a cluster is the highest between the 7-th and 12-th knot.

Variety Muscat red is sensitive to overloading.

CLUSTER. The cluster is medium big - 13,7/8,9 cm; the length varies from 7,7 to $19,5 \mathrm{~cm}$, and the width from 5,7 to $14,0 \mathrm{~cm}$, cylindrically-conical, sometimes with one or two wings, semi-compact to compact. The average weight is from 150 up to $170 \mathrm{~g}$.

GRAPE. The grape is almost spherical, mostly medium large - 13,1/12,7 $\mathrm{mm}$; the length varies from 11,0 up to $16,2 \mathrm{~mm}$, and the width from 10,7 up to $15,7 \mathrm{~mm}$. The average weight is from 1,9 up to $2,9 \mathrm{~g}$. The pellicle is light pink to purple red, with medium thick wax coating, medium thick, elastic, covered by large, dark brown, closely arranged spots (this is typical). The texture of the grape is juicy. The taste is harmonious, gentle, with nice muscat aroma.

PUTTING FORTH AMENTS AND MILLERANDAGE. Variety Muscat red shows tendency towards putting forth aments. Around $26 \%$ of the blossoms fertilize out of around 380 flower buds in the raceme. The millerandaged are around $2,4 \%$.

Evidence shows that after the blossoming around 8-9\% of the racemes will normally fall. This phenomenon is explained not with elongation, but with falling off of the racemes as a result of the formation of an isolating layer in the base of their stem (at the knot) at the complete falling off of the blossoms. 
RESISTANCE TO DISEASES. The variety is sensitive to mildew and oidium. The grapes is practically resistible to grey rot.

PECULIARITIES OF THE AGROCULTURAL ENGINEERING. The formation of Guyot is appropriate for the red Muscatvariety. It can be also cultivated as stem by leaving shorter fruit-bearing sections. When the climatic conditions are unfavorable, then pinching of the shoots should be applied prior to the blossoming.

APPROPRIATE STOCKS. The vines develop and bear fruit well, when they are grafted on the stocks Shasla x Berlandieri 41 B and Berlandieri x Riparia Kober 5 BB. Grafted on the stock Rupestris du Lo, it displays tendency towards transformation of the racemes into suckers (elongation). Variety Muscat red is with increased resistance to phylloxera. In the past the variety was cultivated on their own rootstock in sandy soils.

REACTION TOWARDS THE CONDITIONS OF THE ENVIRONMENT. Muscat red belongs to the most cold-resistant local varieties. It was found out that in the region of Pleven at $-19,1^{\circ} \mathrm{C}$ in 1954 there freezed around $14 \%$ of the main and $3 \%$ of the replacing buds, and at $-20,2^{\circ} \mathrm{C}$ in $1958-44 \%$ of the main and $23 \%$ of the replacing buds. The high cold resistance of the red Muscat variety usually is explained with the duration of the deep rest, in which the buds are, although no such a direct subordination between the two phenomena has been determined so far. According to Рангелов (1977) the buds of Muscat red pass into forced rest during the first half of February. Moskov et al. (1963) determine that first get out of rest and acquire the ability of producing or shooting the buds, which are located at 30th (10.XI), and later at 25-th (12.XII), at 20-th (11.I), at 15-th (14.II) and finally at 10-th knot (17.III).

Variety Muscat red gives best results when it is cultivated in sandy, clay-sandy and gravel soils on hilly terrains. The grapes becomes slightly colored and the muscat aroma in the grain is tasted slighter on level and fertile soils.

MECHANICAL COMPOSITION OF THE GRAPES. Muscat red is a vinous variety as per mechanical composition. The theoretical output of the must is high.

CHEMICAL COMPOSITION OF THE MUST. The grapes of the red Muscat variety amass moderate quantity of sugars, with relatively low titrated acidity and sugar content from $18,6 \%$ up to $21,8 \%$, with the titrated acidity varying from 4,38 up to $6,00 \mathrm{~g} / \mathrm{dm}^{3}$, and do not necessarily provide the freshness, typical for the high quality white dry wines. After transferring to stem cultivation of the vines, the sugar content of the must decreased with $2-3 \%$, which means that it sometimes fails to provide the necessary alcoholic content of the wines.

USAGE OF THE GRAPES AND EVALUATION OF THE PRODUCTION. The grapes of variety Muscat red is used for production of quality white dry wines. They are characterized by very good chemical composition, straw-yellow color, harmonious taste and gentle muscat aroma. The quantity of the phenol substances is little and gives the wines' soft taste .

It is typical for the dry wines of variety Muscat that they develop their taste qualities after one-year maturing.

\section{VARIATIONS AND BRANCHES}

Nedelchev and Kodarev (1956) indicate that the red Muscat variety is known for its two branches with clear red and pink colouring of the grapes. There is a separate white grape variation, which does not differ from the red Muscat variety as per the rest morphological features and economic qualities.

\section{PAMID}

NAME. Grecheskiy rozoviy (USSR), Pamit (France), Rosioara (Romania), Plovdina (Yugoslavia), Piros Szlanka (Hungary), Pamidi (Greece), Saratchoubouk (Turkey), Manakuki (Albania).

SYNONYMS. Adrianopolitika, Ahilo, Balkan pamid, Bar tarnova, Boboshevo pamid, Bov tarnova, Boz tarnova, Light brown pamid, Gaisdut fioletoviy, Garvansko oko, Grecheskiy rozoviy Dorvu gyuven, Doyru giden, Eskiyska Zhuta prachka, Zhalta loza, Koplik, Kuklen pamid, Mana kukya, Marokanskiy vinograd, Odrinka, Balkan Pamid, Boboshevo Pamid, Pamid light brown, Pamid small, Pamid green, Pamid penben, Pamid Chengene, Pamid red, Plovdivana, Plovdiska, Plovdina, Pomida, Razovishka zhalta prachka, Sara chibuk, Thracian pamid, Tarnova, Filebilik, Filibelin, Gypsy Pamid, Tsrvanka, Tsrvena slankamenka, Chergene pamid, Cherveno grozde, Cherveno grozdi, Cherveno sladko grozde, Shasla grecheskaya, Echke meme cherniy.

ORIGIN. Kirimidchi (1927), Constantinescu et al. (1960) consider that Pamid is a Bulgarian variety. Nedelchev (1951) and Nastev (1976) deem that it originated from Thrace, and Avramov, Briza 
(1965) from the Balkan peninsula. Nedelchev (1938) writes that variety Pamid has spread out into former Yugoslavia from Bulgaria.

Analyzing the information about the origin of Pamid grape variety, the concept that it is a Thracian variety should be assumed as the most probable one, describing it as originating in the central part of the Balkan peninsula, from where it is subsequently distributed over the neighboring countries.

Variety Pamid is a typical representative of the Black Sea environmentally-geographic group (Proles pontica Negr.) (fig.2).

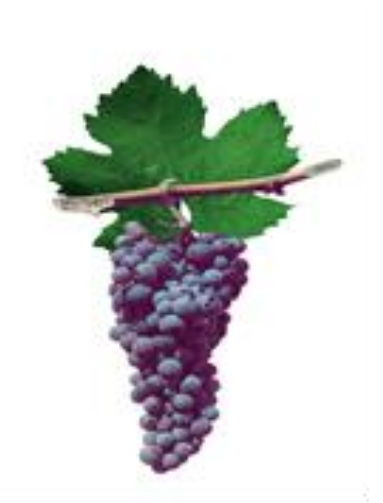

Fig. 2. Pamid

DISTRIBUTION. The variety is distributed in Serbia, Macedonia, Voyvodina and Kosmet. Before the phylloxera crisis it was sparsely propagated in Romania, mostly in Oltenia, Dobrudzha and Moldovian USSR (Constantinescu et al., 1962). It is cultivated in large areas in Hungary, Albania, north Greece and European Turkey (Zirojevic, 1974).

Pamid is one of the most ancient and most common varieties in Bulgaria. According to Viala, Vermorel (1905) it is cultivated from the Rhodope mountains to the Balkan mountains and from the Balkan mountains to Danube. The relative Pamid share of the national vineyard area decreases progressively from $44,6 \%$ in 1931 to $35,7 \%$ in 1938, to $23,8 \%$ in $1955,11,2 \%$ in 1960 and $6 \%$ in 1976. In 1990 it occupies around $15 \%$ of the area of the red vinous varieties. There is a growing tendency for the areas occupied with this variety to grow and as of 2009 its areas have increased to $19 \%$ of the total share of the red vinous varieties (МЗX, „Агростатистика“, 2011). It is zoned for industrial production of grapes in the south, north, east and south-east vine-growing region.

CLUSTER. The cluster is medium big $-14,6 / 9,1 \mathrm{~cm}$; the length varies from 9,0 up to $18,8 \mathrm{~cm}$, and the width from 4,8 up to $13,3 \mathrm{~cm}$. The average weight of the cluster is from 150 up to $297 \mathrm{~g}$.

GRAPE. The grape is oval, medium large - 14,9/13,6 mm; the length varies from 11,7 to $18,2 \mathrm{~mm}$, and the width from 10,7 up to $17,0 \mathrm{~mm}$. The average weight is from 2,3 up to $2,7 \mathrm{~g}$. The pellicle is red, with abundant wax coating, thin and delicate. The texture of the grape is juicy, crunchy and the taste is harmonious.

PERIOD OF VEGETATION. Pamid is a medium ripening vinous variety - the grapes ripes during the second half of September.

GROWING STRENGTH OF THE VINES. The vines have strong growth. The shoots are usually long, thick and right-growing. They develop a few in number and strong growing side shoots.

FERTILITY AND CROP. Variety Pamid has very high fertility and production, which are relatively permanent as per years with ground cultivation and Guyot formation. More than half of the shoots, developed by main buds, have two racemes. Around $1 / 3$ of the shoots, sprouting of replacing and sleeping buds, are fruit-baring.

The variety has high regenerative ability. The racemes are located between 2-nd and 8-th, mainly from 3-th up to 6-th knot of the shoot.

Variety Pamid bears fruit well also with short /limb/ pruning. With it high percentage of the shoots, sprouted from angular eyes, are fruit-bearing.

PUTTING FORTH AMENTS AND MILLERANDAGE. The variety is not inclined to putting forth aments. The millerandage grains are around 8\%.

RESISTANCE TO DISEASES. Variety Pamid is sensitive to mildew and odium. It is attacked strongly by mites and grape-vine moths. The grapes is comparatively resistible to grey rot. The variety 
has increased resistance to phylloxera in view of which it was cultivated in sandy soils on their own rootstock without grafting in the past.

PECULIARITIES OF THE AGROCULTURAL ENGINEERING. The variety is not very demanding towards the ways of cultivation. With ground cultivation and Guyot formation optimum loading is reached up to 20 - 24 eyes. The crops with the Guyot formation as compared to the glass-shaped ones become greater with around $20-30 \%$. Moreover, in case of necessity the shoots of the old vine part may be used for the fruit sections.

With stem cultivation the most appropriate formation is a medium stem chain with short fruit sections. In the event of winter eye overloading of the vines the quality of the grapes decreases, the ripening of the grapes is delayed and the grapes remain pale in color.

APPROPRIATE STOCKS. The vines develop and bear fruit well grafted on the stocks Shasla $\mathrm{x}$ Berlandieri 41 B, Berlandieri x Riparia Kober 5 BB and Berlandieri x Riparia C04.

REACTION TOWARDS THE CONDITIONS OF THE ENVIRONMENT. Pamid variety is not overparticular about the soil-climatic conditions. More preferable are soils with light mechanical composition, on hilly terrains with south exposure. It is comparatively resistible to drought and low winter temperatures. According to Радулов (1969) at $-20^{\circ} \mathrm{C} 72 \%$ of the main and $45 \%$ of the replacing buds suffer extensive damage.

MECHANICAL COMPOSITION OF THE GRAPES. As per mechanical composition of the grapes, Pamid is a vinous variety. The grapes has a low relative share of the solid remainder and high theoretical output of the must.

CHEMICAL COMPOSITION OF THE MUST. The grapes variety Pamid accumulates enough sugars only in certain years and regions with short pruning and optimum loading. Accordingly, the titrated acidity is low (under $5 \mathrm{~g} / \mathrm{dm}^{3}$ ). With stem cultivation and mixed pruning the sugar content is decreased considerably, and the titrated acidity is increased insignificantly.

The technological ripeness of the grapes for production of red dry wines in the typical for the variety regions occurs in the end of September and the beginning of October.

USAGE OF THE GRAPES AND EVALUATION OF THE PRODUCTION. The grapes of variety Pamid is used for production of dry wines. They are light and insufficiently fresh, with light red up to pink color, harmonious taste and pleasant fruity aroma. The wines become fit for consumption immediately after the fermentation and are the most searched for popular consumption.

The grapes of variety Pamid is also used for consumption in fresh condition. It is pleasant for eating - the pellicle and the seeds are not felt. The consumption of the grapes for this purpose starts as early as the beginning of the grapes ripening, since the titrated acidity is low. As for consumption in fresh condition, preference is given to the grapes Pamid black.

\section{VARIATIONS AND BRANCHES}

Variety Pamid has big intravariety diversity. Viala, Vermorel, (1909) mention about Pamid large, Pamid small, Pamid white and Pamid grey. Avramov, Briza (1965) describe the variations Bela plovdina, Crvena plovdina and Crna plovdina. Kirmidchi (1927) describes the variations Pamid white, Pamid black (Kuklen), Pamid red (Thracian, Boboshevo), Pamid Gypsy (Balkan), Pamid grey, Pamid large, Pamid small and Rohavitsa (light brown). Неделчев $(1938,1951)$ marks only three variations - Pamid red, Pamid black and Pamid Gypsy 6.

When examining the intravariety diversity of thePamid variety, no difference is made between variations and branches, and only their economic importance is emphasized. It should be emphasized, however, that they are of little importance, with a few exceptions. It is worth noting that this is applied for ascertainment purposes only, and does not refer to the selective character of the work.

On the grounds of the researches into the intravariety diversity with the Pamid variety, the following generalization can be made. The variety has the following variations: Pamid pink, Pamid black, Pamid grey, Pamid white, Pamid large and Pamid putting forth aments. Pamid pink is the most widespread and is used for processing into wine. Pamid black has a looser cluster, more elongated grapes, with darker /dark-red to black/ coloring and crunchier texture. It is appropriate for consumption in fresh condition. Pamid grey and Pamid white differ from Pamid pink by the very coloring of the grapes. As per economic qualities they do not have any decisive advantages over the Pamid pink. Pamid differs only by the strong putting forth of aments and millerandaged grains, which do not ripe simultaneously. Pamid large is tetraploid and differs from Pamid pink only by its looser cluster and larger and rounder grains. The branch selection with variety Pamid should be directed in two directions - selection of branches for 
grapes processing into wine and selection of branches for consumption in fresh condition. It is also necessary the tetralogical forms of the variety to be separated systematically, which are very frequently met in the old plantations, as well as the forms with decreased fertility of the bloom.

\section{Conclusion}

1. Muscat red is a late ripening vinous variety, and variety Pamid is medium ripening vinous variety with possibility for consumption also in fresh condition as early as the beginning of September, since the pellicle and its seeds are not felt, and the titrated acidity is low.

2. Red Muscat Variety belongs to the most cold-resistant local varieties.

3. Pamid variety has strengthened root phylloxera resistance, in consideration of which it can be cultivated on its own rootstock without grafting in sandy soils.

\section{Acknowledgment}

The research, the results of which are reported in the present paper, was carried out under project NP 6/2020 "Creation of a genbank (mother vineyard) of vine varieties and branches recommended for cultivation in the Republic of Bulgaria" within the frames of TU-Varna research activities financed from the state budget target funds.

\section{References}

Катеров, К., П. Костов 1964. Каталог на сортовете лози в България, Земиздат, 196 с.

Катеров, К., А. Дончев, М. Кондарев, Г. Гетов, Т. Начев, Е. Хершкович, В. Вълчев, М. Маркова, Д. Брайков, Х. Тодоров, П. Мамаров, Й. Иванов, З. Занков, Б. Цанков, Л. Радулов, М. Иванов, М. Жекова. 1990. Българска ампелография, m. 1, Обща ампелография. БАН, София. $296 \mathrm{c.}$

Кирмидчи, Н. 1927. Сортове лози в България (Кратка ампелография), Лом, печ. “Зора”, 105.

Министерство на земеделието и храните. Агростатистика, 2011.

Москов И, М. Ников, Л. Бозова. 1963. Исследвания свободных аминокислот и сахаров в почках виноградной лозы во время вегетации покоя. Доклады АН СССР, 150 (6), 1963.

Настев, Д. 1976. Специално лозарство. Скопие, Универзитетска печатница во Скопие, 99-101,.

Неделчев, Н.1938. Ампелография, Софив, Придворна печатница, 223 с.

Неделчев, Н. 1951. Ампелография, София, Профиздат, 344 с.

Неделчев, Н., М. Кондарев. 1956. Лозарство, София, Земиздат, 328 с.

Радулов, Л.1969. Проучване върху студоустойчивостта на сортовете лози,. - В: науч.тр. ВСИ „В.Коларов” - Пловдив., т. 18, Лозарство и овощарство, Пловдив, „Хр.Г.Данов”, 71-78.

Радулов Л., П. Абрашева, М. Иванов. 2004. Перспективни винени сортове лози за България.

Стоев К., и др. 1960. Райониране на лозарството в България. Научни трудове ЦНИИЛВ.

Т.3. С. - София: Земиздат, 167 с. 
Avramov, L.K.Briza. 1965. Posebno vinogradarstvo (Ampelografia), Novi Sad, Univerzitet u Novom Sadu, 324-327.

Constantinescu, G. et al. 1960. Ampelografi a RPR, Vol. 3, Bucuresti, Editara ARFR, 41-52, 239-262.

Consuantinescu, G. et al. 1962. Ampelografi a RPR, Vol. 4, Bucuresti, Iditura ARFR, 553-563

Constantinescu, G. et al. 1962. Ampelografi a RPR, Vol. 5, Bucuresti, Editura ARFR, 39-53.

Viala, P., V. Vermorel. 1905. Acipelographie, Vol. 6, Paris, Masson et Cie, Editeurs, 393-401.

Viaia, P., V. Vermorel. 1909. Ampeiographie, Vol. 7, Paris, Masson et Cie Editeurs, 17, 55, 149, 234.

Zirojevie, D. 1974. Poznavanje sorata vinove loze. Vol. 1, Beograd, Nolit, 403 p. 